\title{
Kompensasi, Independensi, Profesionalisme dan Etika Profesi Internal Auditor terhadap Kualitas Audit di Inspektorat Jenderal Kementerian Ketenagakerjaan
}

\author{
Aulia Saputra ${ }^{1}$, Dwi Setiawan Susanto ${ }^{2}$ \\ 1,2 Universitas Pancasila, Jl. Raya Lenteng Agung, Jagakarsa, Jakarta Selatan, 12640
}

\section{N F O A R T I K E L JEL Classification:} $H 83$

\section{Keywords:}

audit quality,

competency,

independence, profesionalism, ethic of profession.

\section{A B S T R A C T}

The purpose of this study was to determine and analyze the influence of competence, independence, professionalism and professional ethics of internal auditors to audit the quality of the Inspectorate General of Ministry of Manpower. The data used in this study are primary data obtained through questionnaires distributed to 60 auditors at the Inspectorate I until IV. Tests carried out by the analysis of data using SPSS regression. Based on the test results coefficient of determination, it is known that the competence, independence, professionalism and ethics of auditors affect audit quality by 84,6\%, while the remaining 15,4\% is influenced by other factors. Meanwhile, regression analysis and hypothesis testing showed that the competence, independence, professionalism and ethics of the profession have a significant effect on audit quality either partially or simultaneously.

\section{A B S T T R A K}

Tujuan dari penelitian ini adalah untuk mengetahui dan menganalisis bagaimana pengaruh kompetensi, independensi, profesionalisme dan etika profesi internal auditor terhadap kualitas audit pada Inspektorat Jenderal Kementerian Ketenagakerjaan RI. Data yang digunakan dalam penelitian ini adalah data primer yang diperoleh melalui kuisioner yang disebarkan kepada 60 auditor pada Inspektorat I s.d. IV. Pengujian data dilakukan dengan analsis regresi menggunakan aplikasi SPSS. Berdasarkan hasil uji koefesien determinasi, diketahui bahwa kompetensi, independensi, profesionalisme dan etika auditor mempengaruhi kualitas audit sebesar $84,6 \%$, sedangkan sisanya sebesar 15,4\% dipengaruhi oleh faktor lain. Sementara itu, Hasil analisis regresi dan uji hipotesis menunjukkan bahwa kompetensi, independensi, profesionalisme dan etika profesi memiliki pengaruh yang signifikan terhadap kualitas audit baik secara parsial maupun secara simultan.

\section{Pendahuluan}

Tuntutan masyarakat akan penyelenggaraan pemerintahan yang bersih dan bebas korupsi, kolusi, dan nepotisme (KKN) menghendaki adanya pelaksanaan fungsi pengawasan dan sistem pengendalian intern yang baik atas pelaksanaan pemerintahan dan pengelolaan keuangan negara untuk menjamin bahwa pelaksanaan kegiatan telah sesuai dengan kebijakan dan rencana yang telah ditetapkan serta untuk menjamin bahwa tujuan tercapai 
secara hemat, efisien, dan efektif. Dalam rangka mendukung tercapainya program atau target pemerintah tersebut, diharapkan peran Aparat Pengawas Internal Pemerintah (APIP) yang memiliki tugas pokok dan fungsi pengawasan dapat dioptimalkan. Untuk ituperan Inspektorat Jenderal (ITJEN) sebagai bagian dari Aparat Pengawas Internal Pemerintah (APIP) menjadi sangat penting ditinjau dari sisi urgensitas Tugas Pokok dan Fungsi (Tupoksi) dasar ITJEN sendiri.

Pengawasaninternaladalahmelaksanakan kegiatan audit, reviu, pemantauan, evaluasi dan kegiatan pengawasan lainnya berupa asistensi, sosialisasi dan konsultasi terhadap penyelenggaraantugasdanfungsiorganisasidalam rangka memberikan keyakinan yang memadai bahwa kegiatan telah dilaksanakan sesuai dengan tolak ukur yang telah ditetapkan secara efektif dan efesien untuk kepentingan pimpinan dalam mewujudkan kepemerintahan yang baik. Oleh karena itu, peran APIP menjadi sangat penting dalam menghasilkan audit yang berkualitas sehingga dapat memberikan nilai tambah bagi manajemen dalam mengambil keputusan di masa sekarang dan masa depan. Audit yang berkualitas juga diharapkan dapat memberikan rekomendasi perbaikan di awal, sehingga kegiatan-kegiatan yang dianggap memiliki kekurangan dapat diperbaiki sedini mungkin. Rekomendasi yang tepat dapat mencegah kemungkinan kesalahan yang berlanjut hingga akhir kegiatan.

Pelaksanaan internal audit dilakukan oleh pegawai sendiri, akibatnya banyak pihak yang menganggap bahwa internal auditor tidak independen. Hal ini terjadi karena orang yang melaksanakan audit adalah orang menerima gaji dari organisasi yang diaudit serta yang menjadi objek audit adalah orang-orang yang berinteraksi dengan mereka setiap harinya. Jadi, walaupun "in fact" internal auditor bisa independen, namun "in appereance" tetap terlihat tidak independen.

Auditor internal Inspektorat Jenderal yang melakukan pemeriksaan, sebesar $46,67 \%$ atausebanyak 28 orang memiliki hubungan persaudaraan dengan objek yang diperiksa, seperti anak, adik, kakak, suami, istri, keponakan ataupun orang tua. Hal ini sangat jelas menggambarkan bahwa independensi seorang auditor internal yang memiliki hubungan persaudaraan dipertanyakan serta membuat hasil audit yang jauh dari berkualitas.

Peraturan BPK No.1 Tahun 2007 tentang Standar Pemeriksaan Keuangan Negara menyebutkan dalam semua hal yang berkaitan dengan pekerjaan pemeriksaan, organisasi pemeriksa dan pemeriksa, harus bebas dalam sikap mental dan penampilan dari gangguan pribadi, ekstern, dan organisasi yang dapat mempengaruhi independensinya".

Agar dapat bekerja efesien, efektif dan ekonomis, haruslah dipilih internal auditor yang berkemampuan tinggi, dalam arti auditor tersebut harus memenuhi persyaratan seperti walaupun tidak mutlak harus seseorang yang registered accountant, auditor minimal seorang sarjana muda akuntansi yang mempunyai latar belakang dibidang akuntansi, menguasai komputer dan software-nya, menguasai peraturan-peraturan pemerintah yang menyangkut bisnis proses organisasi yang diaudit dan harus bermoral tinggi, objektif, berjiwa matang, sanggup bekerja keras dan tidak stress menghadapi situasi yang bagaimanapun beratnya.

Auditor yang memiliki latar belakang akuntansi masih dinilai kurang, yaitu sebanyak 10 orang atau $16,67 \%$, jika dibandingkan dengan auditor yang tidak memiliki latar belakang akuntansi, yaitu sebanyak 50 orang atau 83,33\%. Selain itu, auditor yang telah mengkuti pendidikan dan pelatihan (diklat) teknis terkait tugas dan fungsi instansi masih sangat minim, yaitu sebanyak 11 orang atau $18,33 \%$,jika dibandingkan dengan auditor yang telah mengikuti diklat teknis, yaitu sebanyak 49 orang atau $81,67 \%$. Selain kompetensi dan independensi yang harus dimiliki oleh setiap auditor dalam setiap pelaksanaan tugasnya, auditor juga dituntut untuk dapat bersikap profesional. Profesionalisme seorang auditor dapat terlihat dari tingkah laku, keahlian maupun kualitasnya sebagai seorang auditor.

Sikap profesionalisme seorang auditor juga tercermin dari setiap pengambilan keputusan berdasarkan pertimbangan, sehingga lebih hati- 
hati dan bijaksana untuk menghasilkan audit yang berkualitas. Saat ini, yang terjadi adalah auditor menerima segala jenis pemeriksaan yang tidak dikuasainya dengan baik, baik dengan alasan menerima perintah pimpinan maupun untuk memenuhi syarat angka kredit untuk kenaikan pangkat, sehingga kualitas dari audit menjadi tidak maksimal.

Etika dalam sebuah profesi seperti auditor juga dapat mempengaruhi kualitas suatu audit. Auditor yang memiliki etika yang baik diharapkan dapat menghasilkan audit yang berkualitas. Aturan perilaku aparat fungsional pemerintah mengatur perilaku auditor, meliputi pengaturan hubungan antara auditor dengan rekan sekerja, atasan, objek pemeriksaan dan masyarakat.

Selain berpedoman terhadap standar audit yang berlaku, auditor yang memiliki perilaku baik akan melaksanakan tugas auditnya dengan tetap memperhatikan prinsip moral yang berkembang dimasyarakat. Saat ini, penilaian kinerja seorang auditor masih sangat tergantung dengan penilaian atasan, sehingga terkadang menimbulkan kecemasan pada auditor bila tidak mematuhi perintah atasannya, seperti tidak dilibatkan dalam kegiatan audit dan sebagainya. Sehingga auditor yang memiliki moral dan etika yang baik belum tentu dapat menghasilkan suatu audit yang berkualitas.

Suraida (2005) mendefenisikan etika sebagai sikap kritis setiap pribadi atau kelompok masyarakat dalam merealisasikan moralitas, dan etika menghimbau orang untuk bertindak sesuai dengan moralitas. Penelitian ini merupakan modifikasi dari penelitian Agusti dan Pertiwi (2013) yang meneliti pengaruh kompetensi, independensi dan profesionalisme terhadap kualitas audit, dimana dalam hal ini peneliti menambahkan satu variabel dependen lainnya yaitu etika profesi untuk diuji pengaruhnya, baik secara parsial maupun simultan, terhadap kualitas audit. Sehingga tujuan dari penelitian ini adalah untuk mengetahui dan menganalisis bagaimana pengaruh Kompetensi, Independensi, Profesionalisme dan Etika Profesi Internal Auditor terhadap Kualitas Audit, baik secara parsial maupun simultan.

\section{Telaah Teori dan Pengembangan Hipotesis}

Hubungan keagenan merupakan suatu kontrak dimana satu atau lebih orang (prinsipal) memerintah orang lain (agen) untuk melakukan suatu jasa atas nama prinsipal serta memberi wewenang kepada agen membuat keputusan yang terbaik bagi prinsipal. Jika kedua belah pihak tersebut mempunyai tujuan yang sama untuk memaksimumkan nilai perusahaan, maka diyakini agen akan bertindak dengan cara yang sesuai dengan kepentingan prinsipal.

Teori agensi adalah dasar utama untuk menjelaskan hubungan eksekutif kompensasi dengan kinerja. Jensen dan Meckling (1976) dalam Ghozali (2015) di dalam teori agensi menjelaskan hubungan keagenan sebagai kumpulan kontrak anatara pemilik sumber daya ekonomi dengan manajer yang mengurus penggunaan dan pengendalian sumber daya di dalam sebuah perusahaan. Ketika satu orang atau lebih memperkerjakan orang lain untuk memberikan suatu jasa mengelola perusahaan dan pemilik mendelegasikan wewenangnya kepada agen dalam pengambilan keputusan perusahaan merupakan hubungan agensi.

Audit internal menurut Institute of Internal Auditor yang dikutip oleh Picket dalam Agoes (2013) menjelaskan bahwa audit internal adalah kegiatan assurance dan konsultasi yang independen dan objektif, yang dirancang untuk memberikan nilai tambah dan meningkatkan kegiatan-kegiatan operasi organisasi. Audit internal membantu organisasi untuk mencapai tujuannya, melalui suatu pendekatan yang sistematis dan teratur untuk mengevaluasi dan meningkatkan efektivitas dari manajemen resiko, pengendalian dan proses tata kelola.

Dalam pelaksanaannya, auditor yang melakukan audit diharapkan dapat menghasilkan sebuah audit yang berkualitas sehingga tujuan dari audit tersebut dapat tercapai, terutama dalam audit internal, diharapkan dapat memberikan nilai tambah bagi manajemen dalam mengambil keputusan. Selain itu, audit yang berkualitas adalah audit yang dapat ditindaklanjuti oleh auditee. Kualitas ini harus dibangun sejak 
awal pelaksanaan audit hingga pelaporan dan pemberian rekomendasi.

De Angelo (1981) mendefinisikan kualitas audit sebagai probabilitas dimanaseorang auditor menemukan dan melaporkan tentang adanya suatu pelanggaran dalamsistem akuntansi kliennya. Menurut Wibowo (2007), kompetensi adalah suatu kemampuan untuk melaksanakan atau melakukan suatu pekerjaan atau tugas yang dilandasi atas keterampilan dan pengetahuan serta didukung oleh sikap kerja yang dituntut oleh pekerjaan tersebut. Dengan demikian, kompetensi menunjukan keterampilan atau pengetahuan yang dicirikan oleh profesionalisme dalam suatu bidang tertentu sebagai sesuatu yang terpenting, sebagai unggulan bidang tersebut.

Pimpinan APIP harus yakin bahwa latar belakang pendidikan dan kompetensi teknis auditor memadai untuk pekerjaan audit yang akan dilaksanakan. Oleh karena itu, pimpinan APIP wajib menciptakan kriteria yang memadai tentang pendidikan dan pengalaman dalam mengisi posisi auditor di lingkungan APIP. Agar tercipta kinerja audit yang baik maka APIP harus mempunyai kriteria tertentu dari auditor yang diperlukan untuk merencanakan audit, mengidentifikasi kebutuhan profesional auditor dan untuk mengembangkan teknik dan metodologi audit agar sesuai dengan situasi dan kondisi yang dihadapi unit yang dilayani oleh APIP. Untuk itu, APIP juga harus mengidentifikasi keahlian yang belum tersedia dan mengusulkannya sebagai bagian dari proses rekrutmen.

Peraturan BPK No.1 Tahun 2007 tentang Standar Pemeriksaan Keuangan Negara menyebutkan dalam semua hal yang berkaitan dengan pekerjaan pemeriksaan, organisasi pemeriksa dan pemeriksa, harus bebas dalam sikap mental dan penampilan dari gangguan pribadi, ekstern, dan organisasi yang dapat mempengaruhi independensinya. Dengan pernyataan ini, organisasi pemeriksa dan para pemeriksanya bertanggung jawab untuk dapat mempertahankan independensinya sedemikian rupa, sehingga pendapat, simpulan, pertimbangan atau rekomendasi dari hasil pemeriksaan yang dilaksanakan tidak memihak dan dipandang tidak memihak oleh pihak manapun.

Mulyadi (2006) mengungkapkan independensi berarti sikap bebas dari pengaruh pihak lain, tidak tergantung pihak lain dan jujur dalam mempertimbangkan fakta serta adanya pertimbangan yang objective dalam merumuskan dan menyatakan pendapatnya. Pemeriksa juga bertanggung jawab untuk mempertahankan independensi dalam sikap mental (independent in fact) dan independensi dalam penampilan perilaku (independent in appearance) pada saat melaksanakan pemeriksaan. Bersikap obyektif merupakan cara berpikir yang tidak memihak, jujur secara intelektual, dan bebas dari benturan kepentingan. Bersikap independenberarti menghindarkan hubungan yang dapat mengganggu sikap mental dan penampilan obyektif pemeriksa dalam melaksanakan pemeriksaan.

Profesionalisme seorang auditor dapat terlihat dari tingkah laku, keahlian maupun kualitasnya sebagai seorang auditor. Auditor yang profesional akan melakukan tugas sesuai dengan standar yang telah ditetapkan dengan caracara yang tidak merugikan pihak lain sehingga setiap tindakannya dapat bisa diterima oleh setiap unsur. Auditor juga dituntut harus selalu dapat menjaga kapasitas profesionalnya karena hasil pemeriksaan yang tidak profesional justru dapat menyesatkan dan tidak dapat memberikan nilai tambah bagi auditee. Selain itu, auditor dapat menolak penugasan yang tidak sesuai kemampuannya. Sikap profesionalisme seorang auditor juga tercermin dari setiap pengambilan keputusan berdasarkan pertimbangan, seperti pengabdian terhadap profesinya, sehingga lebih hati-hati dan bijaksana untuk menghasilkan audit yang berkualitas.

Hardjana (2002) memberikan pengertian bahwa profesional adalah orang yang menjalani profesi sesuai dengan keahlian yang dimilikinya. Dalam hal ini, seorang profesional dipercaya dan dapat diandalkan dalam melaksanakan pekerjaannya sehingga dapat berjalan lancar, baik dan mendatangkan hasil yang diharapkan. Label profesional disini mengisyaratkan suatu kebanggaan, komitmen pada kualitas, dedikasi pada kepentingan klien dan keinginan tulus 
dalam membantu permasalahan yang dihadapi klien sehingga profesi tersebut dapat menjadi kepercayaan masyarakat.

Perilaku auditor sesuai dengan tuntutan organisasi menurut Baswoko (2006) yaitu setiap auditor wajib menaati peraturan perundangundangan yang berlaku dan melaksanakan tugas kedinasan yang dipercayakan kepadanya dengan penuh tanggung jawab. Sementara itu, Suraida (2005) mendefenisikan etika sebagai sikap kritis setiap pribadi atau kelompok masyarakat dalam merealisasikan moralitas, dan etika menghimbau orang untuk bertindak sesuai dengan moralitas. Moral dan etika memang mempunyai fungsi yang sama yaitu memberikanorientasi bagaimana dan kemana kita harus melangkah dalam hidup ini. Moralitas memberikan manusia aturan atau petunjuk konkrit tentang bagaimana harus hidup, bertindak dalam hidup sebagaimanan manusia yang baik dan menghindari perilaku tidak baik, sedangkan etika berbicara mengenai nilai dan norma moral yang menentukan perilaku manusia dalam hidupnya. Sehingga secara umum etika didefinisikan sebagai nilai-nilai tingkah laku atau aturan-aturan tingkah laku yang diterima dan digunakan oleh suatu golongan tertentu atau individu atau dapat disimpulkan sebagai standar perilaku/seperangkat norma/pedoman yang dapat diterima dimasyarakat dan menjadi dasar penilaian benar atau salah, jujur atau tidak jujur dan adil atau tidak adilnya tindakan internal auditor dalam setiap pelaksanaan audit dengan memperhatikan nilai moralitas.

Dalam pelaksanaan audit, setiap auditor wajib mentaati kode etik yang telah ditetapkan, yaitu integritas, objektivitas, kerahasiaan dan kompetensi. Tindakan yang tidak sesuai dengan Kode Etik tidak dapat diberi toleransi meskipun dengan alasan tindakan tersebut dilakukan demi kepentingan organisasi, atau diperintahkan oleh pejabat yang lebih tinggi. Auditor tidak diperbolehkan untuk melakukan atau memaksa karyawan lain melakukan tindakan melawan hukum atau tidak etis. Pimpinan APIP harus melaporkan pelanggaran Kode Etik oleh auditor kepada pimpinan organisasi.

\section{Pengaruh Kompetensi terhadap Kualitas Audit}

Kompetensi dapat diartikan sebagai keterampilan atau pengetahuan dalam suatu bidang tertentu sebagai sesuatu yang terpenting, sebagai unggulan bidang tersebut. Pada dasarnya kompetensimemilikipengaruhyangpositifdengan terhadap kualitas audit, sehingga dapat dikatakan bahwa seorang auditor yang memiliki komptensi yang dipersyaratkan dapat melaksanakan tugas pemeriksaan secara berkualitas.

Berdasarkan peraturan Menteri Pendayagunaan Aparatur Negara No.220 Tahun 2008 tentang Jabatan Fungsional Auditor dan Angka Kreditnya, selain melalui pengawasan yang dilakukan, seorang auditor harus mampu memenuhi syarat profesi yang telah ditetapkan. Untuk memenuhi salah satu persyaratan kompetensi, seorang auditor diwajibkan memiliki pendidikan minimal sarjana di bidang akuntansi, serta memiliki pengetahuan di bidang auditing, administrasi pemerintahan dan komunikasi. Selain itu, seorang auditor juga harus selalu memperbaharui pengetahuannya, baik mengenai peraturan maupun teknologi. Auditor tidak boleh menggunakan peraturan yang sudah kadaluarsa dalam melakukan tugas pemeriksaan.

Wirasuasti, dkk (2014) dalam penelitiannya menyebutkan bahwa kompetensi berpengaruh positif dan signifikan terhadap kualitas audit, dimana jika auditor memiliki kompetensi yang baik maka auditor dengan mudah melaksanakan tugas-tugas auditnya. Alim, dkk (2007) menyatakan bahwa kualitas audit dapat tercapai jika auditor memiliki kompetensi yang baik. Sementara itu, Agusti dan Pertiwi (2013) menjelaskan dalam penelitiannya bahwa auditor sebagai ujung tombak pelaksanaan tugas audit harus senantiasa meningkatkan pengetahuan yang telah dimiliki. Nugraha (2012) menyimpulkan bahwa kompetensi auditor adalah kualifikasi yang dibutuhkan auditor untuk melaksanakan audit yang benar. Sejalan dengan itu, Kharismatuti dan Hadiprajitno (2012) menunjukkan kompetensi yang terdiri dari pengetahuan dan pengalaman memiliki pengaruh terhadap kualitas audit. 


\section{$\mathrm{H}_{1}$ : Kompetensi berpengaruh signifikan terhadap Kualitas Audit}

\section{Pengaruh Independensi terhadap Kualitas Audit}

Independensi dapat diartikan sebagai sebuah sikap yang harus dimiliki oleh auditor untuk tidak terpengaruh (terbebas) dari segala bentuk gangguan, baik pribadi, ekstern maupun organisasi yang dapat mempengaruhi hasil auditnya dalam setiap penugasan.Dalam sebuah audit, independensi menjadi salah satu faktor yang memegang peranan penting dalam menghasilkan sebuah audit yang berkualitas.

Peraturan BPK No.1 Tahun 2007 tentang Standar Pemeriksaan Keuangan Negara menyebutkan dalam semua hal yang berkaitan dengan pekerjaan pemeriksaan, organisasi pemeriksa dan pemeriksa, harus bebas dalam sikap mental dan penampilan dari gangguan pribadi, ekstern, dan organisasi yang dapat mempengaruhi independensinya. Alim, dkk (2007) menjelaskan independensi berpengaruh terhadap kualitas audit, dimana auditor harus memiliki kemampuan dalam mengumpulkan setiap informasi yang dibutuhkan dalam pengambilan keputusan audit yang harus didukung dengan sikap independen. Agusti dan Pertiwi (2013) dan Wirasuasti, dkk (2014) menyimpulkan bahwa kompetensi berpengaruh signifikan terhadap kualitas audit.

$\mathrm{H}_{2}$ : Kompetensi berpengaruh signifikan terhadap

Kualitas Audit

\section{Pengaruh Profesionalisme terhadap Kualitas} Audit

Profesionalisme Auditor dapat diartikan sebagai sikap dan perilaku auditor dalam menjalankan profesinya dengan kesungguhan dan tanggung jawab agar mencapai kinerja tugas sebagaimana yang diatur oleh organisasi profesi, meliputi pengabdian pada profesi, kewajiban sosial, kemandirian, keyakinan profesi dan hubungan dengan rekan seprofesi.

Auditor yang profesional akan melakukan tugas sesuai dengan standar yang telah ditetapkan dengan cara-cara yang tidak merugikan pihak lain sehingga setiap tindakannya dapat bisa diterima oleh setiap unsur, memiliki kemampuan yang tinggi dan berpegang teguh kepada nilai moral yang mengarahkan serta mendasari perbuatan. Selain itu, auditor dapat menolak penugasan yang tidak sesuai kemampuannya. Sikap profesionalisme seorang auditor juga tercermin dari setiap pengambilan keputusan berdasarkan pertimbangan, sehingga lebih hatihati dan bijaksana untuk menghasilkan audit yang berkualitas. Seorang profesional dipercaya dan dapat diandalkan dalam melaksanakan pekerjaannya sehingga dapat berjalan lancar, baik dan mendatangkan hasil yang diharapkan. Secara sederhana, auditor yang profesional wajib melaksanakan tugas-tugasnya dengan kesungguhan dan kecermatan. Sebagai seorang yang professional, auditor harus menghindari kelalaian dan ketidakjujuran.

Agusti dan Pertiwi (2013) dalam penelitiannya menyebutkan bahwa profesionalisme berpengaruh terhadap kualitas audit, dimana profesionalisme yang diproyeksikan melalui pengabdian sosial, kewajiban sosial, kemandirian, keyakinan terhadap profesi dan hubungan dengan sesama profesi merupakan faktor yang mempengaruhi kualitas audit. Lukyta Arumsari dan Budhiarta (2016) menyatakan seorang auditor yang profesional akan dipercaya dan dapat diandalkan dalam melaksanakan pekerjaannya, sehingga dapat berjalan lancar, baik dan mendatangkan hasil yang diharapkan. Di sisi lain, Nugrahini (2015) menggambarkan bahwa seorang auditor yang profesional, akan mempertimbangkan atau tidaknya informasi dengan tepat, karena hal ini berhubungan dengan jenis pendapat yang diberikan sehingga akan menghasilkan audityang berkualitas. Ida mayasari dalam penelitiannya menyebutkan bahwa seorang auditor yang profesional tidak dapat diintimidasi dan tidak tunduk karena tekanan oleh orang lain guna mempengaruhi sikap dan pendapatnya.

$\mathrm{H}_{3}$ : Profesionalisme berpengaruh signifikan terhadap Kualitas Audit

\section{Pengaruh Etika Profesi terhadap Kualitas Audit}

Etika dapat dikatakan sebagai sikap 
mempertimbangkan atau memperhatikan tingkah laku manusia dalam mengambil suatu keputusan yang berkaitan dengan moral.Etika lebih mengarah pada penggunaan akal budi manusia dengan objektivitas untuk menentukan benar atau salahnya serta tingkah laku seseorang kepada orang lain.

Seorang auditor dalam membuat keputusan pasti menggunakan lebih dari satu pertimbangan rasional yang didasarkan pemahaman etika yang berlaku dan membuat suatu keputusan yang adil (fair) serta tindakan yang diambil itu harus mencerminkan kebenaraan dan keadaan yang sebenarnya. Setiap pertimbangan rasional ini mewakili kebutuhan akan suatu pertimbangan yang diharapkan dapat mengungkapkan kebenaran dari keputusan etis yang telah dibuat, oleh karena itu untuk mengukur tingkat pemahaman auditor atas pelaksanaan etika yang berlaku dan setiap keputusan yang dilakukan memerlukan suatu ukuran.Akuntan yang profesional dalam menjalankan tugasnya memiliki pedoman-pedoman yang mengikat seperti kode etik, sehingga dalam melaksanakan aktivitasnya akuntan publik memiliki arah yang jelas dan dapat memberikan keputusan yang tepat dan dapat dipertanggungjawabkan kepada pihak-pihak yang menggunakan hasil keputusan auditor.

Aini (2013) dalam penelitiannya menyimpulkan bahwa terdapat pengaruh etika profesi terhadap kualitas audit. Sejalan dengan itu, Aini (2009) mendeskripsikan dengan menerapkan etika auditor akan menghasilkan audit yang berkualitas, sehingga laporan audit dapat memberikan yang relevan kepada pengguna. Tarigan dan Bangun (2013) menjelaskan akuntan publik yang memiliki komitmen untuk menerapkan kode etik profesi dapat menghindari segala bentuk pelanggaran-pelanggaran sehingga dapat meningkatkan kualitas auditnya. Sejalan dengan itu, Purnamasari dan Herawati (2013) dalam penelitiannya menyebutkan bahwa etika profesi memiliki pengaruh terhadap kualitas audit.

$\mathrm{H}_{4}$ : Etika Profesi berpengaruh signifikan terhadap Kualitas Audit

\section{Metode}

Populasi penelitian adalah wilayah generalisasi yang terdiri dari objek/subjek yang mempunyai kualitas dan karakteristik tertentu yang ditetapkan oleh peneliti untuk dipelajari dan kemudian ditarik kesimpulannya (Sugiyono, 2012:72). Populasi dalam penelitian ini adalah seluruh auditor Inspektorat Jenderal Kementerian Ketenagakerjaan RI sejumlah 60 orang. Sampel adalah bagian dari jumlah dan karakteristik yang dimiliki oleh populasi. Sedangkan teknik sampling adalah teknik pengambilan sampel (Sugiyono, 2012:116).Dalam penelitian ini dikarenakan populasi yang dibawah 100 orang, peneliti menggunakan seluruh populasi sebagai sampel penelitian yaitu sebanyak 60 orang.

Dalam penelitian ini, peneliti menetapkan kualitas audit merupakan variabel dependen. Seorang auditor internal yang bisa menyelenggarakan proses auditnya dengan baik akan memberikan nilai tambah bagi pihakpihak terkait.Sedangkan variabel bebas dalam penelitian ini adalah kompetensi, independensi, profesionalisme dan etika profesi.Teknik analisis data mencakup uji normalitas, heteroskedastisitas dan multikolinearitas. Uji model penelitian dengan Uji $\mathrm{F}$ dan Adjusted R-Squared. Untuk mendeteksi normalitas data dapat dilakukan pula melaluianalisis statistik yang salah satunya dapat dilihat melalui Kolmogorov-Smirnov test (K-S). Heteroskedastisitas muncul apabila error atau residual yang diamati tidak memiliki variasi yang konstan dari satu pengamatan ke pengamatan lain.Apabila hasil pengujian menunjukkan probabilitas variabel yang lebih dari 0.05 maka tidak terdeteksi adanya heteroskedastisitas. Multikolinearitas dapat dilihat dengan mengamati nilai tolerance dan lawannya yaitu variance inflation factor (VIF). Nilai yang dipakai untuk menunjukan adanya multikolinearitas adalah nilai tolerence $<0,10$ atau sama dengan nilai VIF $>10$. Persamaan regresi dalam penelitian ini:

$$
\mathrm{Y}=\alpha+\beta 1 \mathrm{X} 1+\beta 2 \mathrm{X} 2+\beta 3 \mathrm{X} 3+\beta 4 \mathrm{X} 4+\mathrm{e}
$$

Dimana:

$\mathrm{Y}=$ Kualitas Audit

$\alpha$ = Harga Konstan 
$\beta 1, \beta 2, \beta 3=$ Angka atau arah koefesien regresi, yang menunjukan $\beta 4$ angka peningkatkan ataupun penurunan variabel dependen yang didasarkan variabel independen

$\mathrm{X} 1=$ Kompetensi

$\mathrm{X} 2$ = Independensi

$\mathrm{X} 3$ = Profesionalisme

$\mathrm{X} 4=$ Etika Profesi

Nilai koefisien regresi disini sangat menentukan sebagai dasar analisis, Hal ini berarti jika koefisien $\beta$ bernilai positif $(+)$ maka dapat dikatakan terjadi pengaruh searah antara variabel independen dengan variabel dependen, setiap kenaikan nilai variabel independen akan mengakibatkan kenaikan variabel dependen. Demikian pula sebaliknya, bila koefisien nilai $\beta$ bernilai negatif (-), hal ini menunjukkan adanya pengaruh negatif dimana kenaikan nilai variabel independen akan mengakibatkan penurunan nilai variabel dependen. Uji $\mathrm{F}$ dan uji t dikatakan berpengaruh jika nilai signifikasi hasil pengujian kurang dari $5 \%$.

\section{Hasil Penelitian dan Pembahasan}

Hasil uji normalitas KolmogorovSmirnov pada variabel kompetensi, independensi, profesionalisme dan etika profesi menunjukkan bahwa nilai Asymp. Sig ( 2 tailed) $>0,05$ yaitu 0,627 . Dengan demikian variabel berdistribusi normal, serta membuktikan bahwa model regresi tersebut layak dipakai untuk prediksi variabel terikat. Hasil uji heteroskedastisitas dengan uji Glejser, maka signifikansi setiap variabel independen lebih tinggi dari 0,05 (5\%). Dengan demikian hasil tersebut menunjukkan bahwa tidak ada variabel independen yang signifikan secara statistik memengaruhi residual dari model regresi. Maka dapat disimpulkan bahwa tidak terdapat masalah heteroskedastisitas dalam model regresi penelitian ini. Berdasarkan hasil uji multikolinearitas, nilai VIF empat variabel independen yaitu kompetensi, independensi, profesionalisme dan etika profesi lebih kecil sama dengan nilai 10 dan nilai tolerance lebih besar dari 0,1. Sehingga dapat disimpulkan bahwa tidak ada masalah multikolinearitas antar variabel independen dalam model regresi.

Berdasarkan hasil perhitungan pada tabel 5 (lampiran) diperoleh nilai koefisien determinasi (Adjusted R-Square) sebesar 0,846 . Hal ini berarti bahwa variabel kualitas audit dapat diterangkan variabel kompetensi, independensi, profesionalisme dan etika profesi adalah 84,6 persen sedangkan sisanya sebesar 15,4 persen dipengaruhi oleh variabel lain di luar model penelitian. Rangkuman hasil pengujian sebagaimana tabel berikut.

Persamaan regresi hasil uji dapat disajikan sebagai berikut.

$$
\begin{aligned}
Y= & -2,346+0,614 X_{1}+0,412 X_{2}+0,409 X_{3}+ \\
& 0,319 X_{4}+e
\end{aligned}
$$

\section{Pengaruh Kompetensi terhadap Kualitas Audit}

Dari hasil penelitian membuktikan bahwa kompetensi berpengaruh signifikan terhadap Kualitas Audit, dimana sejalan dengan penelitian Ni Wayan Nistri Wirasuasti, Ni Luh Gede Erni Sulindawati dan Nyoman Trisna Herawati (2014), yang menyatakan bahwa kompetensi berpengaruh secara signifikan terhadap kualitas audit.Seorang auditor yang memiliki tugas pemeriksaan dalam

Tabel 1. Hasil Pengujian

\begin{tabular}{lrrrr}
\hline \multicolumn{1}{c}{ Keterangan } & \multicolumn{1}{c}{ B } & Std. Error & t-hitung & \multicolumn{1}{c}{ Sig. } \\
\hline Kompetensi & 0,614 & 0,150 & 4,107 &, 000 \\
Independensi & 0,412 & 0,199 & 2,071 &, 043 \\
Profesionalisme & 0,409 & 0,116 & 3,522 &, 001 \\
Etika_Profesi & 0,319 & 0,093 & 3,442 &, 001 \\
Constant & $-20,346$ & 70,135 & & \\
R-Square & 0,857 & & & \\
Adjusted R-Square & 0846 & & & \\
F-hitung & 82,110 & & & \\
Sig. F & 0.000 & & & \\
\hline
\end{tabular}


sektor pemerintahan juga dituntut untuk memiliki pengetahuan yang berkaitan dengan administrasi pemerintahan. Dengan wawasan yang luas, tingkat pendidikan yang tinggi, dan pelatihan serta pengetahuan yang dimiliki selama menjadi auditor merupakan dasar yang digunakan dalam menjalankan tugas audit untuk mencapai kualitas yang baik dan dapat dipertanggungjawabkan.

Seperti yang tertuang dalam standar audit APIP disebutkan bahwa audit harus dilaksanakan oleh orang yang memiliki keahlian dan pelatihan teknis cukup sebagai auditor. Dengan demikian, auditor belum memenuhi persyaratan jika ia tidak memiliki pendidikan dan pengalaman yang memadai dalam bidang audit. Peraturan Badan Pemeriksa Keuangan No.01 Tahun 2007 tentang Standar Pemeriksaan Keuangan Negara menyatakan organisasi pemeriksa harus memiliki prosedur rekrutmen, pengangkatan, pengembangan keberlanjutan dan evalasi atas pemeriksa untuk membantu organisasi pemeriksa dalam mempertahankan pemeriksa yang memiliki kompetensi yang memadai. Organisasi pemeriksa juga memiliki tanggung jawab untuk meyakinkan bahwa pemeriksaan dilakukan oleh personil yang memiliki kompetensi profesional dan secara kolektif mempunyai keahlian dan pengatuhan yang memadai.

Dalam setiap pemeriksaan, pemeriksa menggunakan pengetahuan, keahlian dan pengalaman yang dituntut oleh profesinya untuk melaksanakan pengumpulan bukti dan evaluasi obyektif mengenai kecukupan, kompetensi dan relevansi bukti.Dalam melakukan tugas pemeriksaan terhadap sistem keuangan, catatan akuntansi dan laporan keuangan, maka seorang auditor harus memiliki kompetensi yang diperoleh dari pelatihan di bidang akuntansi dan ilmu-ilmu lainnya yang terkait dengan akuntabilitas audit. Selain dituntut untuk memiliki kompetensi tentang standar audit, kebijakan, prosedur dan praktik-praktik audit.

Hasil ini jugasejalan dengan penelitian Restu Agusti dan Nastia Putri Pertiwi (2013) menjelaskan dalam penelitiannya bahwa auditor sebagai ujung tombak pelaksanaan tugas audit harus senantiasa meningkatkan pengetahuan yang telah dimiliki. Disisi yang berbeda, Kisnawati (2012) menuturkan bahwa kompetensi tidak memiliki pengaruh terhadap kualitas audit. Kondisi ini disebabkan masih adanya auditor yang pendidikannya SMA dan Diploma atau tidak sesuai dengan standar audit APIP dimana disebutkan latar belakang auditor minimal S-1.

\section{Pengaruh Independensi terhadap Kualitas Audit}

Penelitian membuktikan bahwa independensi memiliki pengaruh signifikan terhadap Kualitas Audit.Suatu proses audit tidak dibenarkan memihak kepada siapapun, karena apabila seorang auditor kehilangan sikap independensinya walaupun memiliki kompetensi yang tinggi, maka auditor tersebut tidak akan bisa untuk mempertahankan kebebasan pendapatnya. Kredibilitas auditor tentu sangat tergantung dari kepercayaan masyarakat yang menggunakan jasa mereka. Auditor yang dianggap telah melakukan kesalahan maka akan mengakibatkan mereduksinya kepercayaan klien.

Hasil penelitian ini sejalan dengan penelitian Ni Wayan Nistri Wirasuasti, Ni Luh Gede Erni Sulindawati dan Nyoman Trisna Herawati (2014), yang menyatakan bahwa independensi berpengaruh secara signifikan terhadap kualitas audit. Untuk menjaga tingkat independensi sangatlah tidak mudah agar tetap sesuai dengan jalur yang seharusnya. Kerjasama dengan klien yang terlalu lama bisa menimbulkan kerawanan atas independensi yang dimiliki auditor. Selain itu juga berbagai fasilitas yang disediakan oleh kliennya selama penugasan audit untuk auditor. Sehingga auditor akan berada pada posisi yang dilematis karena mungkin akan mudah dikendalikan oleh auditan.

Peraturan Badan Pemeriksa Keuangan No.01 Tahun 2007 tentang Standar Pemeriksaan Keuangan Negara menyatakan bahwa organisasi pemeriksa memiliki tanggung jawab untuk meyakinkan bahwa independensi dan obyektivitas dipertahankan dalam setiap tahap pemeriksaan. Selain itu, dalam semua hal yang berkaitan dengan pekerjaan pemeriksaan, organisasi pemeriksa dan pemeriksa harus bebas dalam sikap mental 
dan penampilan dari gangguan pribadi, ekstern dan organisasi yang dapat mempengaruhi independensinya.

Namun, hasil penelitian ini tidak sejalan dengan penelitian Baiq Kisnawati (2012) yang mengatakan bahwa mutasi pada sektor pemerintah menjadi penyebab independensi tidak bepengaruh terhadap kualitas audit. Auditor yang dimutasikan dari SKPD ke inspektorat sudah saling mengenal dan memiliki hubungan sosial dan rasa kekeluargaan yang dapat mengganggu independensi auditor itu sendiri.

\section{Pengaruh Profesionalisme terhadap Kualitas Audit}

Dalam penelitian ini menunjukkan bahwa profesionalisme berpengaruh signifikan terhadap Kualitas Audit.Seorang auditor internal yang profesional, akan mempertimbangkan material atau tidaknya informasi dengan tepat, karena hal ini berhubungan dengan jenis pendapat yang akan diberikan, sehingga akan menghasilkan audit yang berkualitas. Oleh karena itu, seorang auditor harus selalu dapat menjaga sikap profesionalnya karena terkait terhadap rekomendasi apa yang akan diberikannya dalam sebuah pemeriksaan, sebuah rekomendasi yang salah justru dapat menjerumuskan objek yang diaudit dalam kesalahan yang lebih jauh.

Hasil penelitian ini sejalan dengan penelitian oleh Putri Nugrahini (2015) yang menyatakan terdapat pengaruh signifikan profesionalisme terhadap kualitas audit. Dalam penelitian tersebut mengungkapkan bahwa profesionalisme auditor merupakan salah satu faktor yang penting untuk menghasilkan audit yang berkualitas, karena jika auditor tidak professional dalam menjalankan profesinya, maka laporan audit yang dihasilkan tidak sesuai dengan kenyataan yang ada sehingga tidak dapat digunakan sebagai dasar pengambilan keputusan. Dalam menjaga mutu pemeriksaan, pemeriksa dan organisasi pemeriksa harus menggunakan pertimbangan yang sehat dan profesional. Akan tetapi, hasil penelitian ini bertentangan dengan penelitian Nugraha (2012) yang menyimpulkan bahwa tidak ada pengaruh profesionalisme terhadap kualitas audit.

\section{Pengaruh Etika Profesi terhadap Kualitas Audit}

Dari hasil penelitian membuktikan bahwa etika profesi berpengaruh signifikan terhadap Kualitas Audit.Etika dapat dianggap sebagai sikap kritis setiap pribadi atau kelompok masyarakat dalam merealisasikan moralitas.Etika juga menghimbau orang untuk bertindak sesuai dengan moralitas. Moral dan etika memang mempunyai fungsi yang sama yaitu memberikanorientasi bagaimana dan kemana kita harus melangkah dalam hidup ini.

Moralitas memberikan manusia aturan atau petunjuk konkrit tentang bagaimana harus hidup, bertindak dalam hidup sebagaimanan manusia yang baik dan menghindari perilaku tidak baik, sedangkan etika berbicara mengenai nilai dan norma moral yang menentukan perilaku manusia dalam hidupnya. Dalam setiap penugasan, auditor wajib mematuhi kode etik yang ditetapkan yang merupakan bagian yang tidak terpisahkan dari standar audit. Kode etik ini dibuat bertujuan untuk mengatur hubungan antara auditor dengan rekan sekerjanya, auditor dengan atasannya, auditor dengan auditan (objek pemeriksanya) serta auditor dengan masyarakat.

Hasil penelitian ini konsisten dengan penelitian Amilin (2010) dalam Tarigan, dkk (2013) yang menyatakan bahwa penerapan etika akuntan publik berpengaruh terhadap kualitas audit. Akuntan publik yang memiliki kesadaran untuk selalu bersikap etis berarti memiliki komitmen untuk menerapkan kode etik profesi sehingga dapat menjaga terjadinya pelanggaranpelanggaran terhadap kode etik. Akan tetapi, hasil penelitian ini tidak sejalan dengan penelitian Imansari (2016) yang menjelaskan dalam setiap pemeriksaan, terdapat auditor yang merasa kurang memilki kepercayaan diri yang besar saat mengahadapi berbagai kesulitan, sehingga masih ada auditor yang merasa bahwa berkualitas atau tidaknya suatu laporan audit ditentukan dari rasa kepercayaan diri yang dari auditor tersebut. 


\section{Simpulan, Keterbatasan, dan Implikasi Hasil Penelitian}

Penelitian ini bertujuan untuk mengetahui dan menganalisis bukti empiris pengaruh dari Kompetensi, Independensi, Profesionalisme dan Etika Profesi.Sampel yang digunakan adalah auditor di Inspektorat Jenderal Kementerian Ketenagakerjaan RI. Berdasarkan hasil pengujian yang telah dilakukan, dapat diperoleh kesimpulan Kompensasi, Independensi, Profesionalisme dan Etika Profesi terbukti berpengaruh signifikan terhadap Kualitas Audit, baik secara parsial maupun simultan.

Penelitian ini tidak luput dari beberapa keterbatasanyang dapatdijadikansebagaireferensi untuk penelitian selanjutnya. Keterbatasan penelitian ini antaralain:

1. Penelitian ini memiliki populasi yang sedikit sehingga sampel yang dihasilkan juga sedikit;

2. Keterbatasan variabel independen yaitu kompetensi, independensi, profesionalisme dan etika profesi dalam menjelaskan pengaruhnyaterhadapvariabeldependenyaitu kualitas audit. Masih banyak variabel lain yang diduga berpengaruh terhadapkualitas audit.

3. Kemungkinan kesalahan dalam mengartikan setiap butir kuisioner oleh responden serta keterbatasan waktu peneliti kepada responden dalam menjelaskan butir-butir kuisioner sehingga berkemungkinan kurang dipahami oleh responden.

Dalam penelitian mendatang perlu menambahkan variabel lain seperti objektivitas, waktu audit dan kompensasi sebagai variabel independen, karena sangat memungkinkan variabel lain tersebut yang tidak dimasukan dalam penelitian ini berpengaruh terhadap kualitas audit. Riset mendatang lebih baik menambah jumlah sampel penelitian.

Bagi pimpinan APIP Inspektorat Jenderal Kemnaker RI agar memberikan reward atau punishment yang jelas bagi auditor yang berprestasi maupun yang terbukti membuat kesalahan. Auditor internal agar dibekali dengan kemampuan teknologo informasi terkait dengan rencana penerapan sistem audit berbasis eletronik (e-audit). Bagi regulator, diharapkan menjadi sumbangan pemikiran untuk dapat membuat regulasi yang lebih tepat mengenai penugasan audit agar dapat menghasilkan pelaksanaan audit yang lebih berkualitas.

\section{Daftar Rujukan}

Agus, S., 2013. Auditing. Salemba Empat. 2013. Agusti, R., \& Pertiwi, N. P. (2013). Pengaruh Kompetensi, Independensi dan Profesionalisme Terhadap Kualitas Audit (Studi Empiris Pada Kantor Akuntan Publik Se Sumatera). Jurnal Ekonomi, 21(03).

Alim, M. N., Hapsari, T., \& Purwanti, L. (2007). Pengaruh Kompetensi dan Independensi terhadap Kualitas Audit dengan Etika Auditor sebagai Variabel Moderasi. Simposium Nasional Akuntansi X, 26-28.

Imansari, P. F., \& Halim, A. (2016). Pengaruh Kompetensi, Independensi, Pengalaman Dan Etika Auditor Terhadap Kualitas Audit (Studi Empiris Pada Auditor Kantor Akuntan Publik Di Kota Malang). Jurnal Riset Mahasiswa Akuntansi, 4(1).

Kharismatuti, N., \& Hadiprajitno, P. B. (2012). Pengaruh Kompetensi dan Independensi Terhadap Kualitas Auditdengan Etika Auditor Sebagai Variabel Moderasi (Studi Empiris Pada Internal Auditor BPKP DKI Jakarta) (Doctoral dissertation, Fakultas Ekonomika dan Bisnis).

Kisnawati, B. (2012). Pengaruh kompetensi, independensi, dan etika auditor terhadap kualitas audit (studi empiris pada auditor pemerintah di inspektorat kabupaten dan kota se-pulau lombok). Jurnal Bisnis dan Kewirausahaan, 8(3), 158-169.

Lukyta Arumsari, A., \& Budiartha, I. K. (2016). Pengaruh Profesionalisme Auditor, Independensi Auditor, Etika Profesi, Budaya Organisasi, Dan Gaya Kepemimpinan Terhadap Kinerja Auditor Pada Kantor Akuntan Publik Di Bali. E-Jurnal Ekonomi dan Bisnis Universitas Udayana, 5(08). 
Mulyadi. 2006. http://ilmuakuntansi.web.id/ pengertian-auditing-menurut-ahli/.

Najib, A. D. R. (2013). Pengaruh keahlian, independensi, dan etika terhadap kualitas audit (Studi pada Auditor Pemerintah di BPKP Perwakilan Provinsi Sul-Sel). Skripsi. Makasar: Universitas Hasanuddin Makasar.

Nugraha, M. E. (2012). Pengaruh independensi, kompetensi dan profesionalisme terhadap kualitas audit (Doctoral dissertation, Widya Mandala Catholic University Surabaya).

Nur'aini, C. (2013). Pengaruh Kompetensi. Independensi Dan Etika Auditor Terhadap Kualitas Audit (Studi Empiris Pada Inspektorat Karanganyar Dan Surakarta), Skripsi, Fakultas Ekonomika dan Bisnis Universitas Muhammadiyah Surakarta.

Peraturan Badan Pemeriksan Keuangan RI No. 01 Tahun 2007 tentang Standar Pemeriksaan Keuangan Negara

Peraturan Menteri Pendayagunaan Aparatur Negara RI Nomor: PER/04/M.PAN/03/2008 tentang Kode Etrik Aparat Pengawasan Intern Pemerintah

Peraturan Menteri Pendayagunaan Aparatur Negara RI Nomor: PER/05/M.PAN/03/2008 tentang Standar Audit Aparat Pengawasan Intern Pemerintah

Purnamasari, D., \& Hernawati, E. (2013). Pengaruh Etika Auditor, Pengalaman, Pengetahuan dan Perilaku Disfungsional terhadap Kualitas Audit. Neo-Bis, 7(2), 119135.

Putri Nugrahini, P. (2015). PENGARUH KOMPETENSI DAN PROFESIONALISME AUDITOR INTERNAL TERHADAP KUALITASAUDIT(StudiEmpirispadaBUMN dan BUMD di Kota Yogyakarta) (Doctoral dissertation, Fakultas Ekonomi).

Tarigan, M. U., \& Susanti, P. B. (2013). Pengaruh Kompetensi, Etika, dan Fee Audit Terhadap Kualitas Audit. Jurnal Akuntansi, 13(1).

Undang-Undang Nomor 1 Tahun 2004 tentang Perbendaharaan Negara.

Undang-Undang Nomor 15 Tahun 2004 tentang Pemeriksaan Pengelolaan dan Tanggung Jawab Keuangan Negara.
Undang-Undang Nomor 17 Tahun 2003 tentang Keuangan Negara.

Wirasuasti, N. W. N., Sulindawati, N. L. G. E., SE Ak, M., Herawati, N. T., \& AK, S. (2014). Pengaruh Kompetensi, Independensi, dan Motivasi Terhadap Kualitas Audit Aparat Inspektorat Dalam Pengawasan Keuangan Daerah (Studi Empiris pada Inspektorat Pemerintah Kabupaten Bangli dan Inspektorat Pemerintah Kabupaten Buleleng). JIMAT (Jurnal Ilmiah Mahasiswa Akuntansi S1), 2(1). 